Volume 9, No.1, January - February 2020

International Journal of Advanced Trends in Computer Science and Engineering

Available Online at http://www.warse.org/IJATCSE/static/pdf/file/ijatcse120912020.pdf

https://doi.org/10.30534/ijatcse/2020/120912020

\title{
The Impact of IT Capability and Supply Chain Agility in the Electronic Home Appliance Retail at Indonesia
}

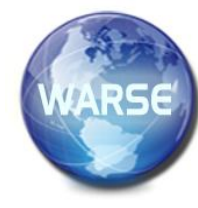

Arya Permadi ${ }^{1}$, Tirta Nugraha Mursitama ${ }^{2}$, Mohammad Hamsal $^{3}$ and Agustinus Bandur ${ }^{4}$

${ }^{1}$ Bina Nusantara University, Indonesia, aryapermadi.binus@gmail.com

${ }^{2}$ Bina Nusantara University, Indonesia, tmursitama@ binus.edu

${ }^{3}$ Bina Nusantara University, Indonesia, mhamsal@binus.edu

${ }^{4}$ Bina Nusantara University, Indonesia, abandur@binus.edu

\section{ABSTRACT}

This study aims to examine the impact of IT and Supply Chain Management capabilities on competitive advantage directly or mediated by Business Agility in the Electronic Home Appliances retail industry in Indonesia. The purpose of this research is to build a theoretical model to examine the relationship between latent variables using a questionnaire to collect research data. In a conceptual framework, Information Technology Capability is a second-order latent variable and consists of three first-order latent variables, Supply Chain Management is a second-order latent variable and consists of five first-order latent variables and Business Agility is a second-order latent variable and consists of four First-order latent variables and competitive advantage second-order latent variables and consist of three first-order latent variables. To explain the relationship between these latent variables, structural equation modeling (SEM) is used to test the goodness of fit of theoretical models and research hypotheses. This study uses 229 Electronic Stores home appliances in JABODETABEK (Greater Jakarta) as research subjects. It is the first empirical study that contributes empirical analysis in the electronic home appliances retail industry to illustrate the role of Information Technology, Inertia Culture and Business Agility capabilities in excellence in the context of the electronic home appliances retail industry in Indonesia.

Key words : Business Agility, competitive advantage, Information Technology Capability, supply chain agility.

\section{INTRODUCTION}

With Indonesia's GDP equivalent to Turkey and the Netherlands, and annual economic growth rates in the range of $5.8-6.4 \%$, Indonesia is predicted to be the 4th largest economic power in the world in $2050(1,2)$. More than $95 \%$ of businesses in Indonesia are family owned and contribute to $25 \%$ of GDP (1). Growth among Indonesian family businesses over the past 12 months has increased 65\% compared to 2016. Including 35\% among seeing double-digit growth. Globally, $69 \%$ of family businesses are growing while Indonesian family businesses as much as $87 \%$ expect to grow over the next two years (3)

From the results of research conducted by (3) of 2953 respondents used semi-structured interviews with key decision makers in a family business with sales turnover of more than Rp. 70 billion per year. It was found that the main challenges for Indonesian family businesses in the next two years were access to the right skills and abilities, the need to innovate in order to stay ahead, the economic environment and competition. In terms of important personal and business goals, maintaining the best talent (through recruitment and retention) for business is very important besides innovation and profitability are also key. But interestingly half said they had a formal medium-term strategic plan while the other $17 \%$ did not have a plan. In addition More than one third (35\%) of Indonesian family businesses hope to change their business models over the next two years and $81 \%$ say they will bring professional expertise from outside the family (3).

In the electronic retail industry technical consumer goods (home appliances) the players are in the form of family business and are experiencing problems in sales decline. Greater Jakarta has a contribution of $60 \%-70 \%$ of total national sales (4). The fall in sales transactions was illustrated through the conditions of sales of electronic home appliances products. Especially at white goods category at the other side this category is important for home appliances electronics retailers because sales from this category contribute the most to their sales. Generally their sales ranging from $60-80 \%$ of total sales but the white goods category also consumes both display and storage locations. (warehouse). Sales data of 3 (three) product categories successfully obtained from GFK shows sales value for washing machine, refrigerator and television product categories decreased from year to year. The decrease in market size experienced by washing machines, refrigerators and flat screen TVs in 2017 compared to data from sales in 2012 ranged from 13\%, 35\% and 36\% (4). This has resulted in increasingly intense competition among retail stores to compete for market share in sales of the three categories of existing electronic home appliances products. Though these three types of home appliances products are the main component of the sale of electronic home appliances retailers. 
Home appliances electronic retailers need business agility as a solution to compete in the uncertainty and turmoil that occurs. The ability of electronic home appliances retail stores can feel the changes that occur in the external and internal environment then how the store responds through improvisation of internal operational processes that involve customers in search activities and make the most of the ability of partners in the business network.

Business agility is very important in a rapidly changing business environment as is the case in the electronic home appliances retail industry. Information technology (IT) is a significant business platform for today's digital economy, the role of IT in creating agility has become an important issue. IT capability plays an important role in its complementarity with business processes, contributing to competitiveness in business processes which in turn contributes to the company's competitive advantage. This is in line with the findings of (1) the majority of respondents agreed to statements about digital technology: $90 \%$ agreed The need for companies to adapt to the digital world. Then $87 \%$ of respondents stated that digitalization will help increase awareness / sensitivity of the company and $87 \%$ of respondents understand the real business benefits that can be achieved with digitalization and realistic planning to measure the benefits obtained.

Through the practice of Supply Chain Management (SCM) electronic retail stores, home appliances are also able to increase competitive advantage. The infrastructure of electronic home appliances retail stores is likely to be different from the infrastructure available in large home appliance electronics retail stores, whereas the infrastructure of electronic home appliances retail stores has been identified as an effective SCM enabler. In addition to infrastructure differences, small home appliance electronics retail stores tend to differ from their larger competitors in competitive strategies, corporate learning styles, and positions in the supply chain structure. Home appliance electronic retail supply chain as one of the important business processes that provide strong support to achieve retailer agility.

\section{LITERATURE REVIEW AND RESEARCH HYPOTHESIS}

\subsection{Family Business}

(5) and (6) Family Business is a business that is regulated and / or managed with a view to forming and pursuing business visions held by dominant coalitions controlled by the same or a number of family members small families in a potentially sustainable way across generations. Based on this definition, a family business is a business because its vision is formed and pursued by a dominant coalition controlled by a family or a small number of families. Significantly, this definition does not specify certain family members who have a vision, owner or management group. Nor does it state that this vision must serve only the interests of the family because the desired future may be partly related to society at large. Changes in the environment make entrepreneurs think differently, work more closely with all stakeholders and respond quickly to customer needs, including businesses that are managed by families. This condition often makes the company focus on building value in the long run and forget about increasing business flexibility (7). Combining traditional management styles full of traditional and family values with the obvious challenges of maintaining business agility is one of the most important tasks of any business owner.

(6) states that in examining issues of strategic redefinition and organizational competitiveness, sooner or later, enter the field of business agility. For as many have encountered over the years, Agility finally arises in executives and scholars, with strategic thinking and attitudes that are in line with unpredictable market conditions. In the family business triangle, strategy and innovation, agility emerges as a missing component that gives others direction, context and purpose.

(8) define Strategic Agility as a series of business initiatives that can be immediately implemented by companies including core competencies, infrastructure, and employees' ability to change. The company's ability to organize and coordinate these elements into integrated resource groups results in the company's ability to be superior to competitors, becoming different competencies.

The same view, also given by (9) emphasizes the need to build organizational resilience, that is, the ability to bounce back from destructive disruptions in the business environment. Agile companies can not only quickly adapt, but can, in fact, take advantage of opportunities that arise at both the tactical and strategic levels. Simply put, because change never ends, so does the advantage of agile business over non-agile business.

It is necessary to implement major changes to achieve agility, modify internal organizations, develop structures that are more streamlined and flexible, in addition to adopting appropriate processes and attitudes, which make it possible to react quickly to adjust the business. This situation is reflected in the way companies look for creative sources of competitive advantage, diverting from resources (eg, capital), to "softer" elements, such as human resource management, innovation, and more creative procedures. Organizations, who realize that the search for other forms of lasting and strategic competitive advantage, is actually nothing more than a quick strategy game. Where regulations change and competitive advantage does not last long. The skills most valued in this condition are reflexive adaptability, rapid innovation, and the development of new abilities as a strategic necessity $(6,10)$. Ultimately, in a business world that is constantly changing 
shape, without lasting competitive advantage, the only true competitive advantage comes from the agility of a business to innovatively keep pace with change when most cannot.

\subsection{Retail}

Retail is an important chain in the process of distribution of goods and is the last chain in a distribution process. Through retail, a product can meet directly with its users. The retail industry here is defined as an industry that sells products and services that have been added to meet the needs of individuals, families, groups, or end users, in accordance with the Retail definition of (11)

Many retailers also expand their reach, which means that their offers overlap and competition increases. Most retailers provide merchandise and services for their customers. This phenomenon has become one of the important missions of retail to always have four elements: getting the right product in the right place at the right price at the right time. How retailers run their business began to change as a result of technological developments. Technology enables companies to create new business models that change the shape of the industry (12).

The impact of technological developments is rapidly influencing the way consumers conduct activities in the retail market. Consumers not only shop online, but actually combine online and offline shopping practices. Retail channels from multichannel are now forced to move towards what is called Omnichannel retail. Omnichannel retailing refers to an integrated shopper experience that combines physical stores with an information-rich digital environment, with the aim of providing an excellent shopper experience in all areas.

Multichannel retailing itself is defined as "A form of distribution strategy to serve customers using more than one sales channel to manage customers in a consistent and coordinated manner across all channels or media used" (13). Retail omnichannel on the other hand is explained by (14) as: "an integrated sales experience that combines the advantages of a physical store with an information-rich experience about online shopping." From this definition it is clear that the Omnichannel concept involves the integration of various channels to serve customers in a customized way through preferred channels.

\subsection{Competitive Advantages}

Theories in strategic management have extensively identified characteristics that provide competitive advantage to companies. For example, competitive advantage can come from barriers to market entry, market position, resources and company-specific capabilities or dynamic capabilities (15). Although research has identified sources of determinants of competitive advantage, surprisingly it does not provide a clear definition of competitive advantage $(15,16)$
According to (17) There are two basic types of competitive advantage: cost leadership and differentiation. (18) states that gaining a competitive advantage is a strategic goal by systematically creating returns above average to defeat competitors on a defensible basis.

(19) offers a comprehensive framework that first links resources to sustainable competitive advantage and superior competitiveness. RBT itself has actually been used to theorize the relationship between causes (eg. sources) and effects (eg. competitive advantages \& performance). According to (19), company resources that are able to form competitive advantage have valuable, rare, difficult to imitate, and non-substitutable characteristics.

The definition of competitive advantage that is considered most consistent with the resource-based view (19) and the perspective of leadership in the market (17) is the definition of competitive advantage from (20), that is a company has a competitive advantage if the company is able to create economic value (namely the difference between the perceived benefits of a combination of the ability of resources and economic costs to exploit it) more than competitors in general in the market.

This study uses the definition of competitive advantage is the ability of companies to exploit opportunities, neutralize threats and reduce costs above the industry average manifests exploitation of market opportunities, neutralization of competitive threats and cost reduction (15).

\subsection{Business Agility}

(21) states that business models, dynamic capabilities, and strategies are interdependent. The strength of a company's dynamic capabilities helps shape its expertise in the design of business models. Through its effects on organizational design, business models influence the dynamic capabilities of companies and the feasibility of certain strategies.

The company's ability to feel, seize opportunities and maintain competitiveness through enhancing, merging, protecting, and, if necessary, reconfiguring the intangible and tangible business assets of the company is very necessary. Through dynamic capabilities, companies will be able to make rapid changes in responding to external triggers or changes in business direction $(22,23)$. Often large businesses are not without substantial costs and risks and companies in terms of competition will have difficulty if the system designed does not refer to the concept of agility (agility) because business processes are increasingly complex and varied (24). The need for business agility to deal with change is no longer a point of debate for any organization (25). 
The dimensions of Business Agility from (22) and (26) are combined into one entity in the definition of Business Agility (27) namely the ability to feel external and internal changes that are highly uncertain, and react reactively or proactively, based on innovation from internal operational processes, involving customers in exploration and exploitation activities, while utilizing the capabilities of partners in business networks.

In this study the definition of the concept of business agility is used (27), namely: the ability to feel external and internal changes that are very uncertain, and respond proactively, based on innovation from internal operational processes, involving customers in exploration and exploitation activities , besides utilizing the ability of partners in business networks.

\subsection{Business agility affects competitive advantage}

Through the development of theory-based models and careful empirical investigations of proposed models, revealed a significant and different impact of firm agility on proven sustainable competitive advantage. The influence between IT capabilities and operational capabilities in building business agility. The significant impact of business agility on competitive advantage has also been examined. Found to be significantly influential in influencing competitive advantage. (28) research shows that the company's agility and network structure are a source of competitive strategies that are very important for company competitiveness.

(29) contributed to the influence of IT capabilities on company competitiveness fully mediated by business agility. This research not only establishes theoretical reasons but also provides supporting empirical evidence, thereby advancing understanding of IT capabilities and their implications for competitiveness.

Based on the description above, the first hypothesis is formulated as follows:

H1: The business agility of the electronic home appliances retailers affects competitive advantage.

\subsection{Information Technology Capability}

IT alone does not produce sustainable competitive advantages in the retail industry, but several companies have benefited from using IT to utilize intangible human and business resources besides complementing each other such as flexible culture, strategic planning, IT integration, and supplier relations. The impact of modern IT on company systems can be classified into three categories, namely: accelerating activities, providing intelligent and autonomous decision making processes and enabling distributed and collaborative operations where the three categories affect agility (30).

Furthermore (36) provides a resource-based perspective on IT capabilities and company competitiveness. (33) states several areas need to be carefully evaluated in developing and implementing IT projects so that they can affect competitive advantage in companies. Technological sophistication, management skills, and integration of resources are the main problems when implementing IT decisions. Investments in IT applications in companies can affect IT competencies and superior IT capabilities, which can then result in lower costs, agility, innovation, added value to customers, and better customer service. Companies can also improve business performance by utilizing IT capabilities through increasing revenue, reducing costs, or both so that it will ultimately produce a competitive advantage for the company.

The role of information technology in increased dexterity has been assessed in recent years. Some conceptual works have suggested an enabling role, while several others have also suggested the role of activating information technology in dexterity (34). They also stated that information technology is generally considered an enabler of company agility. A common premise is that greater information technology investment enables companies to become more agile. However, it is not uncommon that information technology can also hinder and sometimes even hinder company agility.

In this study the definition of IT capabilities used is (31), which is the company's ability to mobilize and utilize IT-based resources in combination with other resources and capabilities.

\subsection{IT Capability affects competitive advantage mediated by business agility}

Through the development of theory-based models and careful empirical investigations of proposed models, (35) revealed a special complementary relationship between IT capabilities and operational capabilities in building company agility. The significant and different impact of company agility on competitive advantage is proven. Therefore on IT resources that need more attention are IT human resources and intangible information-enabled technology resources. (36) expressed almost the same opinion, only they added that the company's IT capabilities present characteristics of value, rarity, non-imitation and non-substitution, their impact on the company's competitive advantage is entirely mediated by the agility of the company's business.

(34) revealed that IT capability is very important to achieve agility while spending more IT does not affect greater agility. Companies must continually maintain and develop superior IT company capabilities to successfully manage and utilize IT resources to build agile organizations. (29) also conducted a study of 214 business executives from manufacturing companies in China, showing that although the company's IT capabilities present characteristics of scarcity, suitability, non-reproducibility, and non-substitution, their impact on 
company competitiveness is entirely mediated by the agility of the company's business processes.

Based on the description above, the second hypothesis is formulated as follows:

H2: IT capability electronic home appliances retailers to influence competitive advantage is mediated by business agility

\subsection{Information technology capability affects competitive advantage}

(31) states the form of IT capability resources in 3 (three) ways namely IT infrastructure, human IT skills, and intangible IT features. They also develop the idea of IT as an organizational capability created by a synergistic combination of IT resources present with other organizational resources and capabilities. Empirical analysis examines the influence between superior IT capabilities and superior company competitiveness and finds the effect to be positive and significant. In addition, the relationship between IT capabilities with competitive advantage is also evidenced by $(33,37)$.

(38) conduct research that investigates the impact of information technology (IT) on agility as measured by the ability to feel and respond to market changes, and the impact of agility on company competitiveness. Data was collected from 193 U.S. manufacturing companies The results show that IT increases the ability to feel market changes, increases the ability to respond to market changes. Importantly, the results show that increased agility has a positive impact on company sales, market share, profitability, speed to market, and customer satisfaction.

Furthermore (39) conducted a study of the effect of IT on competitive advantage mediated by knowledge management. Using data from 168 companies in China provides empirical evidence that three types of IT resources (IT infrastructure, IT people, and IT relations) positively influence knowledge management capabilities (KMC), which are positively related to competitive advantage.

Based on the description above, the third hypothesis is formulated as follows:

H3: Information Technology Capability electronic home appliances retailers affect the company's competitive advantage.

\subsection{Supply Chain Agility}

The importance of supply chain management in logistics is influential in the home appliance electronics retail industry, because there is a close relationship between business activities (marketing) and logistics activities (40). In companies that are market oriented, this supply chain management is becoming increasingly important. Amid unprecedented changes in the market caused by rising customer expectations, globalization, shrinking product life cycles, rapid technological innovation and an uncertain supply have led to an era of turbulence.

Supply Chain itself as a set of three or more entities (companies or individuals) that are directly involved in the upstream and downstream flow of products, services, finance, and / or information from sources to customers. Supply chain management is a systemic system, coordinating both strategically from traditional and tactical business functions in all business functions in a particular company and in all business elements in the Supply Chain, with the aim of improving the long-term competitiveness of each - each company and the Supply Chain as a whole (41).

Effective supply chain management has become a potential way to secure competitive advantage and improve company competitiveness because this form of competition in the business environment is no longer limited to the company level but also enters the supply chain (55). To explain the concept of agility in the context of the supply chain, which has now become an important characteristic of the best value supply chain (44). Businesses that rely solely on the traditional model find it increasingly difficult to overcome this volatility. The company's responsiveness to change and customer satisfaction has emerged as the key to success in such turbulence. By some research dexterity has been identified as the key to the company's response as well as customer satisfaction. That some studies have claimed agility as an attribute is closely related to the effectiveness of supply chain agility strategies (44).

This study uses the definition of supply chain agility as a systemic system, coordinating both strategically from traditional and tactical business functions across all business functions within a particular company and across all business elements in the Supply Chain, with the aim of increasing long-term competitiveness of each company and the overall Supply Chain (41) because it is more in line with the competitive situation in the home appliance electronics retail industry in Indonesia.

\subsection{Supply chain agility affects competitive advantage mediated by business agility}

Combining processes and relationships, collaboration in a supply chain is defined as a partnership process in which two or more autonomous companies work together to plan and carry out supply chain operations towards mutual goals and mutual benefits (45). Their results indicate that supply chain collaboration increases excellence collaboratively and does have an influence on company competitiveness, and collaborative advantage is an intermediate variable that enables supply chain partners to achieve synergies and create superior performance. 
(46) in his research proved that it is not enough just to have a flexible manufacturing, distribution and procurement system to achieve supply chain agility. Flexibility in managing requests is also needed. For this reason, demand and supply integration within a company is very important to achieve supply chain agility.

(44) in his research advanced the theory by using secondary data to investigate the impact of FSCA (Firm Supply Chain Agility) on financial performance by including the mediating effects of Customer effectiveness (CUST) and Cost Efficiency (COST). FSCA was found to have a positive impact on the company's financial results with a positive impact on CUST and COST. However, no direct effect was found between FSCA and financial performance. This is an interesting finding since (47) found a positive influence between supply chain agility and financial performance.

For this reason, based on the description above, the fourth hypothesis is formulated as follows:

H4: Supply chain agility affects competitive advantage mediated by business agility

\subsection{Supply chain agility affects competitive advantage}

Research on the supply chain has been carried out by several researchers. (48) show that supply chain agility of a company is directly and positively influenced by the level of flexibility that exists in the manufacturing and procurement / supply chain processes; meanwhile, it is indirectly affected by the level of flexibility in the distribution / logistics process. (47) from his research note that IT integration enables companies to take advantage of supply chain flexibility which in turn results in higher supply chain agility and ultimately excellence in terms of more competitive business performance.

(49) examine the performance implications of an integrated supply chain strategy, with customer service performance followed by performance. The research model was tested using data from a sample $(\mathrm{n}=57)$ from 150 automotive suppliers in North America. The results show a direct positive relationship between supply chain integration and customer service, and customer service and company performance. The relationship of supply chain integration with indirect financial performance but through customer service; that is, customer service was found to fully mediate the relationship between supply chain integration and company performance for suppliers in the automotive industry. The relationship between supply chains and competitive advantage is also found in research conducted by $(47,60,65)$.

For this reason, based on the description above, the fifth hypothesis is formulated as follows:

H5: Supply chain dexterity in home appliance electronic retailers influences the company's competitive advantage.

\section{RESEARCH DESIGN}

\subsection{Research Framework}

Based on literature review and research hypotheses, this study establishes the research framework described in Figure 3. The study aims to examine 2 independent (exogenous) variables, namely: Information Technology Capability and supply chain agility directly influence the dependent variable (endogenous) competitive advantage and indirect dependent variable (endogenous) competitive advantage through Business Agility.

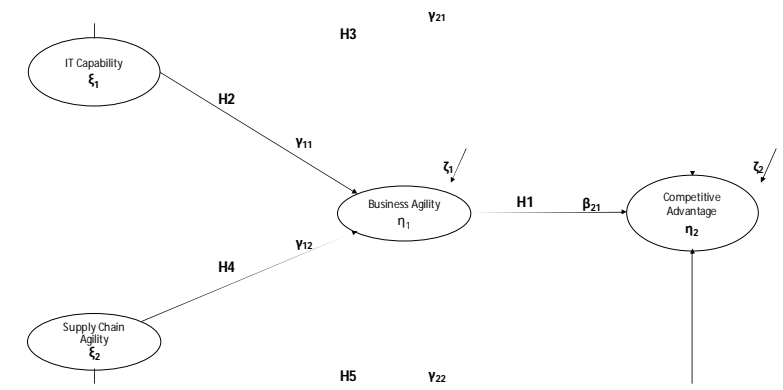

Figure 1: Research Framework \& Hypothesis

\subsection{Questionnaire Design}

Design questionnaire is based on a literature review of previous research. Based on that the Questionnaire was compiled which was divided into 4 (four) sections: information technology capability (reference from $(29,31,39)$ ), supply chain agility (references from $(41,44,53,54))$, business agility (reference from $(26,55,56))$, and competitive advantage $((15,57))$. All items were evaluated using a 6 (six) point Likert scale, where a higher score indicates a stronger level of agreement

\subsection{Sampling}

The sampling technique used in this quantitative study is cluster random sampling based on cities that are in accordance with the percentage distribution of the number of shops per Jabodetabek area. The unit of analysis in this research is an electronic home appliances retail store, represented by the shop owner / General Manager. They were chosen because they were considered to have sufficient knowledge about business operational activities, getting to know existing competitors and business decision makers.

This study assumes that the tolerable error (e) is $5 \%$ and the confidence interval is $95 \%(\mathrm{Z}=1.96)$. So based on (58) and (59) using a modification of the standard formula from (60) to calculate the sample size obtained by the number $n=229$ (rounding) then in this study the number of samples was set at 229 respondents from the population of electronic home appliances retail stores in Jabodetabek is 560. This sample size is determined by considering the analytical techniques used in hypothesis testing using Structural Equation Modeling using the LISREL version 8.8 application. 
Retrieval of data through a questionnaire by visiting directly one by one respondent in accordance with the target number of respondents described above. Data retrieval was carried out in the period June 2019 to September 2019. The amount of data collected was 237 respondents but valid only 229 because it was in accordance with the target respondents to be achieved then the data collection was stopped.

\section{ANALYSIS AND RESULTS}

SEM bridges theoretical and empirical knowledge to enable a better understanding of the real world. This analysis establishes a causal relationship between latent variables and observed variables. Through the model we can determine how latent variables depend on the observed variables. Figure 1 illustrates the results of the hypothesized model used in this study, which represents the standard structural coefficients.

\subsection{Measurement Model Analysis}

Analysis of the measurement model is done using confirmatory factor analysis to determine whether the research variables have sufficient validity and reliability to measure the structural model.

\section{A. First Order Confirmatory Factor Analysis (1st CFA)}

The CFA model that shows the relationship between latent variables and observed variables as indicators of related latent variables. In this test, the indicator is declared valid if it has a standardized factor loading (SFL) $\geq 0.5$ and the construct is declared reliable if it has a Construct Reliability (CR) value $\geq$ 0.7 or Average Variance Extracted (AVE) $\geq 0.5$.

The results of the First Order Confirmatory Factor Analysis (1st CFA) test can be seen in appendix 1. Of the total 13 IT capability indicators that passed the CFA test, only 9 items, 15 supply chain agility indicators that passed the CFA test only 14 indicator items, 12 indicator items all business agility passed the CFA test, and 10 items of business excellence indicators passed the CFA test 9 indicator items. After the CR and AVE tests are carried out, then proceed to the next stage.

\section{B. Second Order Confirmatory Factor Analysis (2nd CFA)}

The 2nd CFA shows the relationship between latent variables at the first level as indicators of a second level latent variable. In this section the researcher uses the calculation of the Latent Variable Score (LVS) for the estimation of indicators that were previously dimensions.

Based on the estimation results of all research variables, the results obtained for the 15 dimensions have a standardized factor loading (SFL) value $\geq 0.5$ so that all dimensions are valid for use as a measurement tool in the study (table 2). Apart from the standardized factor loading (SFL) value, it produces a Construct Reliability (CR) value $\geq 0.7$ and Average Variance Extracted (AVE) $\geq 0.5$ for the 4 variables, so that all variables are judged to be reliable for use in research.
Table 1: Validity \& Reliability $2^{\text {nd }}$ CFA all Varibles \begin{tabular}{|l|l|l|l|l|l|}
\hline Dimensions/Items & $S F L \geq 0.5$ & Error & $C R \geq 0.7$ & AVE $\geq 0.5$ & Results \\
\hline
\end{tabular}

\begin{tabular}{|c|c|c|c|c|c|}
\hline \multicolumn{3}{|c|}{ KEMAM TI } & \multirow[t]{2}{*}{0.93} & \multirow[t]{2}{*}{0.84} & \multirow{2}{*}{$\begin{array}{c}\text { Reliabel } \\
\text { Valid }\end{array}$} \\
\hline KTPSD & 0.93 & 0.13 & & & \\
\hline KTPBD & 0.89 & 0.21 & & & Valid \\
\hline KTIRD & 0.93 & 0.13 & & & Valid \\
\hline \multicolumn{3}{|c|}{ MRANPAS } & 0.91 & 0.74 & Reliabel \\
\hline M RPKD & 0.98 & 0.04 & & & Valid \\
\hline MRPAD & 0.75 & 0.45 & & & Valid \\
\hline M RPTD & 0.89 & 0.20 & & & Valid \\
\hline MRPCD & 0.78 & 0.39 & & & Valid \\
\hline MRPFD & 0.88 & 0.23 & & & Valid \\
\hline \multicolumn{3}{|c|}{ TANGBIS } & 0.88 & 0.71 & Reliabel \\
\hline KBIPD & 0.93 & 0.13 & & & Valid \\
\hline KBIRD & 0.95 & 0.10 & & & Valid \\
\hline KBITD & 0.77 & 0.40 & & & Valid \\
\hline KBIAD & 0.70 & 0.51 & & & Valid \\
\hline \multicolumn{3}{|c|}{ UNGSAIING } & 0.83 & 0.70 & Reliabel \\
\hline KBEPD & 0.94 & 0.14 & & & Valid \\
\hline KBNAD & 0.86 & 0.26 & & & Valid \\
\hline KBBYD & 0.70 & 0.22 & & & Valid \\
\hline
\end{tabular}

\subsection{Structural Model Analysis}

Analysis of this structural model includes: Evaluation of the Overall Fit of the Model and Analysis of Causal Relations, including evaluation of the T-Value and the Structural Equation Coefficient. Testing of structural models in this study uses the Maximum Likelihood method that produces Goodness of Fit Statistics as shown in Figure 2. Results from Goodness of Fit Index (GFI) and the hypothesized model shows a good match. Root So that the overall structural model of this study can be concluded statistically as having a good model fit.

Table 2: Goodness of Fit Statistics

\begin{tabular}{|c|c|c|c|c|}
\hline GOODNESS OF FIT Index & Value & Result & Criteria & Means \\
\hline \multirow{2}{*}{ Statistic Chi-Square } & \multirow{2}{*}{139.63} & \multirow{2}{*}{ Fit } & $0 \leq \mathrm{X} 2<2 \mathrm{df}$ & Fit \\
\hline & & & $2 \mathrm{df} \leq \mathrm{X} 2<3 \mathrm{df}$ & Acceptable \\
\hline \multirow{2}{*}{ p - Value } & \multirow{2}{*}{0.000} & \multirow{2}{*}{ Acceptable } & $0.05 \leq p<1.00$ & Fit \\
\hline & & & $0.01 \leq p<0.05$ & Acceptable \\
\hline \multirow{3}{*}{$\begin{array}{l}\text { Root Mean Square Error of } \\
\text { Aproximation (RMSEA) }\end{array}$} & \multirow{3}{*}{0.058} & \multirow{3}{*}{ Close Fit } & RM SEA $<0.05$ & Close Fit \\
\hline & & & $0.05 \leq$ RMSEA $<0.08$ & Adequate/Good Fit \\
\hline & & & $0.08 \leq$ RMSEA $<0.1$ & Mediocre Fit \\
\hline \multirow{2}{*}{ Normed Fit Index (NFI) } & \multirow{2}{*}{0.98} & \multirow{2}{*}{ Good Fit } & $\mathrm{NFI} \geq 0.90$ & Good Fit \\
\hline & & & $0.80 \leq \mathrm{NFI}<0.90$ & Marginal Fit \\
\hline \multirow{2}{*}{ Non-Normed Fit Index (NNFI) } & \multirow{2}{*}{0.99} & \multirow{2}{*}{ Good Fit } & $\mathrm{NNFI} \geq 0.90$ & Good Fit \\
\hline & & & $0.80 \leq \mathrm{NNFI}<0.90$ & M arginal Fit \\
\hline Persimony Normed Fit Index (PNFI) & 0.74 & Good Fit & $\mathrm{PNFI} \geq 0.5$ & Good Fit \\
\hline \multirow{2}{*}{ Confirmative Fit Index (CFI) } & \multirow{2}{*}{0.99} & \multirow{2}{*}{ Good Fit } & $\mathrm{CFI} \geq 0.97$ & Good Fit \\
\hline & & & $0.90 \leq \mathrm{CFI}<0.97$ & M arginal Fit \\
\hline \multirow{2}{*}{ Incremental Fit Index (IFI) } & \multirow{2}{*}{0.99} & \multirow{2}{*}{ Good Fit } & $\mathrm{IFI} \geq 0.90$ & Good Fit \\
\hline & & & $0.80 \leq \mathrm{IFI}<0.90$ & Marginal Fit \\
\hline \multirow{2}{*}{ Relative Fit Index (RFI) } & \multirow{2}{*}{0.97} & \multirow{2}{*}{ Good Fit } & $\mathrm{RFI} \geq 0.90$ & Good Fit \\
\hline & & & $0.80 \leq \mathrm{RFI}<0.90$ & M arginal Fit \\
\hline \multirow{2}{*}{ Standardized RMR (SRMR) } & \multirow[t]{2}{*}{0.04} & \multirow{2}{*}{ Fit } & $S R M R \leq 0.05$ & Fit \\
\hline & & & $0.05<$ SRMR $\leq 0.10$ & Acceptable \\
\hline \multirow{2}{*}{ Goodness of Fit Index (GFI) } & \multirow{2}{*}{0.92} & \multirow{2}{*}{ Good Fit } & $\mathrm{GFI} \geq 0.90$ & Good Fit \\
\hline & & & $0.80 \leq \mathrm{GFI}<0.90$ & Acceptable \\
\hline \multirow{2}{*}{ Adjusted Goodness of Fit Index (AGFI) } & \multirow{2}{*}{0.89} & \multirow{2}{*}{ Good Fit } & AGFI $\geq 0.89$ & Good Fit \\
\hline & & & $0.80 \leq \mathrm{AGFI}<0.89$ & Marginal Fit \\
\hline Persimony Goodness of Fit Index (PGFI) & 0.61 & Fit & PGFI $\geq 0.5$ & Fit \\
\hline
\end{tabular}




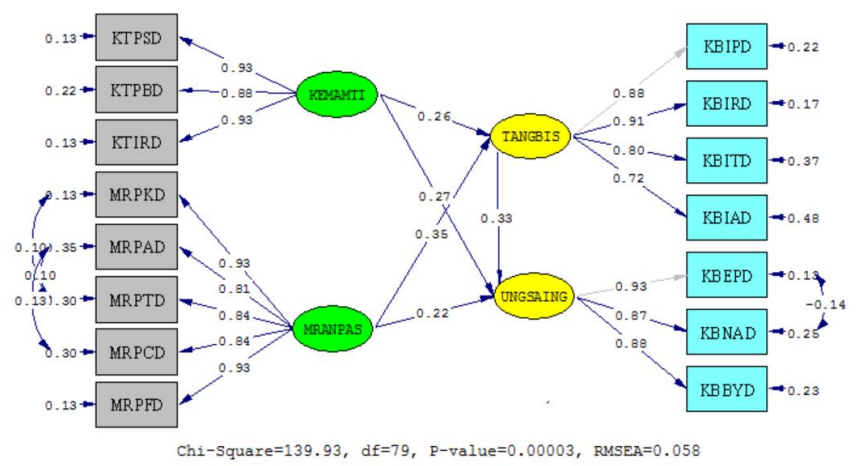

Figure 2: Basic Model - Standardized Solution Path Diagram

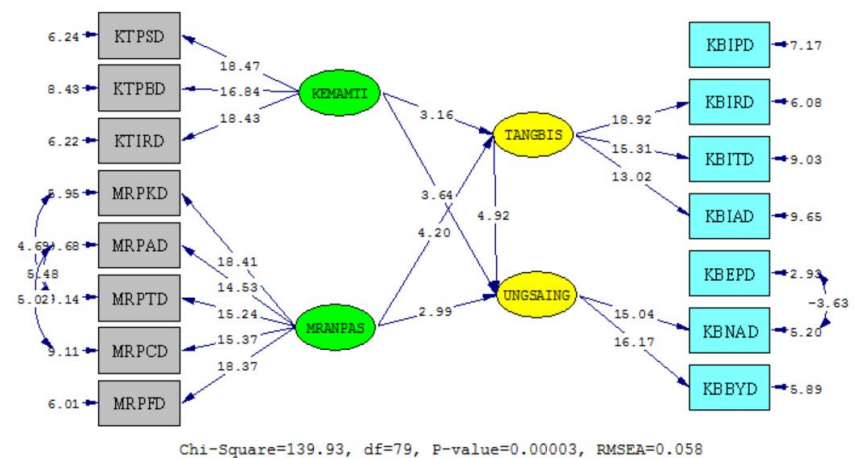

Figure 3: Basic Model - T Values Path Diagram

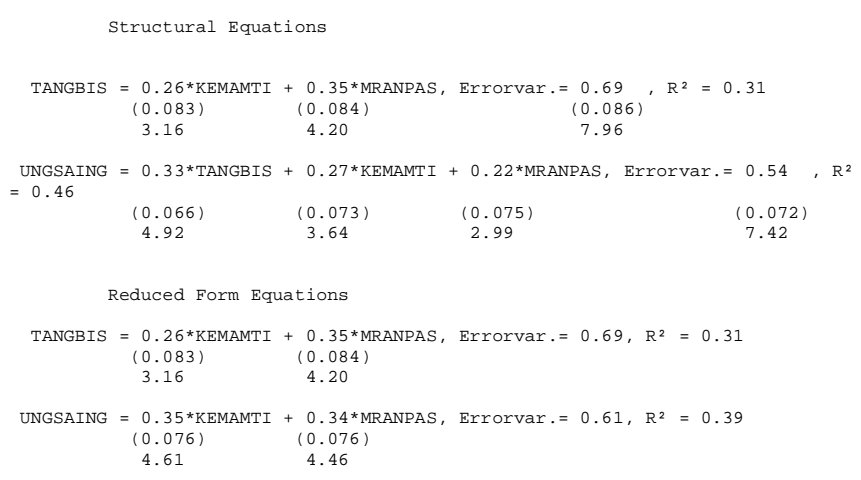

Figure 4: Equations

Figure 4 shows that the business agility variable, IT capability, and supply chain management of home appliance electronic retailers together have an influence on the company's competitive advantage. The effect given is shown by the value of the Coefficient of Determination $\left(\mathrm{R}^{2}\right)$ produced by Structural Equations that is equal to 0.46. This means that the business agility, IT capability, inertia culture, and supply chain management of the electronic home appliance retailers simultaneously or jointly have an influence of $46 \%$ on the variable competitive advantage of the company.

Furthermore, from figure 4 it is also known that the ability of IT and supply chain management of the electronic retailer home appliance together has an influence on business agility. The effect given is shown by the value of the Coefficient of Determination $\left(\mathrm{R}^{2}\right)$ produced by Structural Equations that is equal to 0.31 (Figure 7). This means that the ability of IT and supply chain management of home appliance electronic retailers simultaneously or jointly has an influence of $31 \%$ on the company's business agility variable.

\subsection{Hypothesis Analysis}

Proof of hypothesis is done by looking at the path-coefficient and t-value (Fig. 2 \& Fig3). the path-coefficient indicates the nature of the relationship between constructs (positive or negative), while The t-value indicates the significance of the construct. Proof of hypothesis can be obtained after going through structural equations obtained from structural model analysis.

Table 3: Hypothesis Test Result

\begin{tabular}{|l|r|r|r|r|r|}
\hline \multicolumn{1}{|c|}{ Path } & \multicolumn{1}{c|}{ Path Coefficients } & \multicolumn{1}{c|}{ T-value } & T-table & \multicolumn{2}{c|}{ Results } \\
\hline Hypothesis 1 & 0.33 & 4.92 & 1.96 & Ho rejected & Significant \\
\hline Hypothesis 2 & 0.26 & 3.16 & 1.96 & Ho rejected & Significant \\
\hline Hypothesis 3 & 0.27 & 3.64 & 1.96 & Ho rejected & Significant \\
\hline Hypothesis 4 & 0.35 & 4.20 & 1.96 & Ho rejected & Significant \\
\hline Hypothesis 5 & 0.22 & 2.99 & 1.96 & Ho rejected & Significant \\
\hline
\end{tabular}

Based on the path diagram and SEM Lisrel output results in table 3 it can be seen that all hypotheses have a t-value for greater than the t-table value. From these values it can be concluded that the null hypothesis ( $\mathrm{H} 0)$ is rejected and significant.

Table 4: Direct, Indirect and Total Effects

\begin{tabular}{|l|c|c|c|c|}
\hline \multirow{2}{*}{\multicolumn{1}{c|}{ PATH }} & \multirow{2}{*}{ DCE } & \multicolumn{2}{c|}{ ICE } & \multirow{2}{*}{ TCE } \\
\cline { 3 - 5 } & & TANGBIS & IICE & \\
\hline KEMAMTI $\rightarrow$ TANGBIS & 0.26 & - & & 0.2600 \\
\hline MRANPAS $\rightarrow$ TANGBIS & 0.35 & - & & 0.3500 \\
\hline TANGBIS $\rightarrow$ UNGSAING & 0.33 & - & - & 0.3300 \\
\hline KEMAMTI $\rightarrow$ UNGSAING & 0.27 & 0.0858 & 0.0858 & 0.3558 \\
\hline MRANPAS $\rightarrow$ UNGSAING & 0.22 & 0.1188 & 0.1188 & 0.3388 \\
\hline
\end{tabular}

Table 4 results of statistical tests on the direct causal effect (DCE), indirect causal effect (ICE), and total causal effect (TCE). Business agility in this research model is a mediating variable, a variable that theoretically influences the relationship between exogenous variables and endogenous variables into an indirect relationship that cannot be observed and measured. The form of mediation of business agility is partial mediating (partial mediating variables) both in the relationship between: IT capability variables with competitive advantage and supply chain management variables with competitive advantage. Veriabel mediation becomes important in explaining the relationship between exogenous and endogenous constructs.

In addition, the magnitude of the value of the direct effect coefficient (DCE) KEMAMTI (0.27) and MRANPAS (0.22) on UNGSAING. The value of the coefficient of direct influence of the two variables is greater than the value of the coefficient of indirect effect (ICE) of the KEMAMTI variable (0.0858) and MRANPAS (0.1188). Next, when we consider the value of the coefficient of direct effects, the variables MRANPAS (0.35) and KEMAMTI (0.26) on TANGBIS. 
The conclusion that can be drawn from the results of this statistic is that IT capability has a greater direct impact on competitive advantage when compared to the availability of business agility. Business agility can reduce the inert culture of electronic home appliance retailers in Greater Jakarta. So business agility as a form of business model plays a good role in increasing the competitive advantage of electronic home appliances retail stores in Greater Jakarta.

\section{RESULT AND DISCUSSION}

The results of this study have theoretical implications relating to strategic management researchers by helping to test the measurement tool for the construct of competitive advantage using the concept of competitive advantage measure from (15). Measuring instruments used in this study were developed and have empirical indicators of competitive advantage. Measurement of competitive advantage based on a strategic management perspective, market leader perspective, resource-based outlook and dynamic capabilities.

The results of this study address the existence of harmony with the findings of (15), the only difference with the findings of (15) is the validity of the CFA test conducted on the indicators and dimensions of cost reduction in this study. These findings also enrich the construct of competitive advantage. So the results of this study contribute to the Competitive Advantage Theory in terms of valid and reliable measuring tools to empirically investigate research hypotheses based on Competitive Advantage in the field of Strategic Management based on resource-based views and dynamic capabilities.

Furthermore, business agility as a form of business strategy or business model in this study was found to have the effect of business agility on competitive advantage. Through empirical evidence its role as a mediator was also evident in this study, thereby adding empirical evidence relating to the research gap related to the role of business agility among IT capabilities.

The direct and indirect influence of positive and significant IT capabilities on competitive advantage in this research is proven through strong empirical support. This result enriches the theory of information technology capability as an internal resource and contributes to the view of the relationship between IT capabilities and Competitive Advantage.

Whereas supply chain management as in this study shows a positive and significant relationship of supply chain management to competitive advantage and this is in line with the results of previous studies. It also proved the existence of a positive and significant relationship of supply chain management to competitive advantage through business agility that is in line with the results of previous research.
The main contribution of research on supply chain management theory relates to the direct versus indirect influence (through mediation variables) on competitive advantage. This research begins by evaluating the literature and then statistically testing whether there is a direct or indirect effect (Fully Mediated or Partial Mediating). This research contributes to supply chain management theory in its relation as a resource of competitive advantage (61) through strong empirical support.

In addition to providing theoretical implications, this research also provides managerial implications. This research involves respondents whose business form is Family Business which has the characteristics of a business form that is owned, controlled, and run by two or more family members and most of them ownership or control are in the family. Family involvement in business makes it unique because it is usually in terms of ownership and management.

The use of resources directly to achieve competitive advantage can be done when the company is in a situation of "mimetic businesses". Mimetic businesses themselves are triggered by the presence of mimetic inertia (62) in companies. Mimetic inertia is an inertia that arises as a result of the process of imitation. Mimetic inertia arises because one company makes another company, generally incumbent as a model.

If the incumbent company system is already widely used in the industry and is deemed suitable or quite good and there is no further review of what exactly is the company's needs and whether the current system really serves their needs. So smaller companies don't have time to look for the most suitable option and this can cause them to blindly follow industry norms.

The organization has 2 choices of internal resources that can be used to realize its competitive advantage, namely: first, the ability of information technology. As an internal resource that affects competitive advantage directly or indirectly. The ability of IT as an internal resource has been proven as one of the resources needed to obtain Competitive Advantage.

IT capability related to utilizing facilities and infrastructure is a top priority for home appliance electronics retailers in Jabodetabek. Through a digital data management system (collection, storage, regulation, use) and supported by adequate computers to complete work and increase the ability to do business collaboration with external partners based on information technology.

Whereas home appliance electronics retailers who own 2 or more units need to consider using business agility to realize their competitive advantage. In this condition, home 
Arya Permadi et al., International Journal of Advanced Trends in Computer Science and Engineering, 9(1), January - February 2020, 833 - 844

appliance electronics retailers need to pay more attention to supply chain management factors because it has the highest influence on achieving business agility. Home appliance electronics retailers in managing supply chain management must pay attention to changes in the market and identify them as business opportunities. Followed by direct, firm decision making to deal with market changes and opportunities arising from changes.

Home appliance electronics shop owners should try to create a win-win situation that all individuals involved to achieve business synergy and compete with other supply chain stores. The Desire to Compete and Surpass each other causes each party to prioritize their own interests at the expense of the other party. This is very dangerous for collaboration and it will worsen and destroy relationships. Long-term relationships such as supply chain collaboration must be motivated by shared intentions, goal conformity, and benefit sharing. As such, home appliance electronics store owners need to align their goals and benefits with Supply Chain partners to create Collaborative Advantages. Such collaborative advantage does indeed directly improve financial performance for each partner in the chain.

The collaboration referred to here is between supply chain partners by utilizing the creation of market knowledge. Because of the vast diversity of knowledge if distributed throughout the supply chain, collaboration will provide an ideal platform for learning and facilitate the creation of partner market knowledge. Supply chain collaboration can also be an effective way to transfer new technical knowledge and skills across parties. It is often difficult for home appliance electronics stores to buy certain skills in the market because of their closed nature. A party might have a better chance of achieving its objectives in gaining new skills and competencies by collaborating with other parties who are role models in that field.

The importance of having business agility in a dynamic business environment will allow home appliance electronics retailers to react better to unexpected changes. Home appliance electronics retailers can synergize all information detected to better understand changes in customer preferences, market segments, and competition development strategies.

Thus, this allows home appliance electronics retailers to take advantage of the benefits of the first move so as to avoid some unforeseen risks and losses. Another implication is the value of strategic networks (Customers, Operations and Partnerships) that are formed as business agility reinforcement. It is important for home appliance retail store owners to consider the Business Agility factor when they want to achieve Competitive Advantage.

\section{REFERENCES}

1. PricewaterhouseCoopers. Family business survey 2014 Findings for Indonesia [Internet]. 2014.

2. World Bank. Indonesia: Overview [Internet]. 2015 [cited 2016 Jul 18].

3. PricewaterhouseCoopers. Family business survey 2018: Indonesia report [Internet]. 2018.

4. Gfk Market Insight. GfK Market Insight Macroeconomics \& Curated News. Vol. 2016. 2017.

5. Chua JH, Chrisman JJ, Sharma P. Defining the Family Business by Behavior. Entrep Theory Pract. 1999;23(4):19-39.

6. Thrassou A, Vrontis D, Bresciani S. The Agile Innovation Pendulum: Family Business Innovation and the Human, Social, and Marketing Capitals. Int Stud Manag Organ [Internet]. 2018;48(1):88-104.

7. Lewandowska A, Sajdak M. Consequences of value-based management for developing the organisational agility potential of a family business. 2013.

8. Weill P, Subramani M, Broadbent M. Building IT infrastructure for: Strategic agility. MIT Sloan Manag Rev. 2002;44(1):57-65.

https://doi.org/10.2139/ssrn.317307

9. Sheffi Y. The resilient enterprise: overcoming vulnerability for competitive advantage. Massachusetts Inst Technol Cambridge, MA MIT Press. 2005;

10. Chebbi H, Yahiaoui D, Vrontis D, Thrassou A. Building Multiunit Ambidextrous Organizations-A Transformative Framework. Hum Resour Manage. 2015;54(1):155-77.

11. Grewal D, Weitz B, Levy M. Retailing Management. Vol. 43. McGraw Hill; 2014. 1109 p.

12. Christensen CM, Tedlow RS. Patterns of Disruption in Retailing. Harv Bus Rev [Internet]. 2000 Jan 1 [cited 2019 Oct 7];78(1):42-42.

13. Stone M, Hobbs M, Khaleeli M. Multichannel customer management: The benefits and challenges. J Database Mark. 2002;10:39-52.

14. Rigby. The Future of Shopping. Harvard Buiness Rev. 2011;(December).

15. Sigalas C, Economou VP. Revisiting the concept of competitive advantage. J Strateg Manag [Internet]. 2013;6(1):61-80.

16. Rumelt RP, Kunin E. What in the World is Competitive Advantage ? Policy Work Pap [Internet]. 2003;1-5.

17. Porter ME. Competitive Strategy: The Core Concepts. In: Competitive Advantage: Creating and Sustaining Superior Performance. 1985.

18. Schoemaker PJH. Strategy, Complexity, and Economic Rent. 1990;(May 2016). https://doi.org/10.1287/mnsc.36.10.1178

19. J.B. B. Firm resources and sustained competitive advantage. J Manage [Internet]. 1991 Mar 1 [cited 
Arya Permadi et al., International Journal of Advanced Trends in Computer Science and Engineering, 9(1), January - February 2020,833 - 844

2016 Oct 15];17(1):99-120.

20. Peteraf MA, Barney JB. Unraveling the resource-based tangle. Manag Decis Econ. 2003;24(4):309-23.

21. Teece DJ. Business models and dynamic capabilities. Long Range Plann [Internet]. 2018;51(1):40-9.

22. Sharifi H, Zhang Z. A Methodology for achieving agility in manufacturing organisations: an introduction. Int J Prod Econ. 1999;62(1):7-22.

23. Saputra N, A SB, Kuncoro EA, Nusantara UB. Developing Work Engagement and Business Agility for Sustainable Business Growth in Indonesia Oil Palm Industry. J Adv Res Dyn Control Syst. 2015;4(1):1302-12.

24. Mukerjee S. Student Information Systems--Implementation Challenges and the Road Ahead. J High Educ Policy Manag [Internet]. 2012;34(1):51-60.

25. Siddharta. Review of agile supply chain implementation frameworks. Int $\mathrm{J}$ Bus Perform Supply Chain Model [Internet]. 2016 [cited 2017 Sep 24];8(1):27-45.

26. Sambamurthy V. Shaping Agility through Digital Options: Reconceptualizing the Role of Information Technology in Contemporary Firms. MIS Q. 2003;27(2):237-63. https://doi.org/10.2307/30036530

27. van Oosterhout $\mathrm{M}$, Waarts E, van Heck E, van Hillegersberg J. Business Agility: Need, Readiness, and Alignment with IT Strategies. Agil Inf Syst Conceptualization, Constr Manag. 2007;44(0):52-69.

28. Yang C, Liu H. Boosting firm performance via enterprise agility and network structure. Manag Decis [Internet]. 2012;50(6):1022-44.

29. Chen Y, Wang Y, Nevo S, Jin J, Wang L, Chow WS. IT capability and organizational performance: The roles of business process agility and environmental factors. Eur J Inf Syst [Internet]. 2014;23(3):326-42.

30. Huang C-Y, Nof SY. Enterprise agility: a view from the PRISM lab. Int J Agil Manag Syst. 1999;1(1):51-60.

31. Bharadwaj A. A resource-based perspective on information technology capability and firm performance: an empirical investigation. MIS Q. 2000;24(1):169-96.

32. Bharadwaj AS, Sambamurthy V, Zmud RW. IT capabilities: theoretical perspectives and empirical operationalization. Manage Sci. 1999; Charlotte, (January):378-85.

33. Bilgihan A, Okumus F, Nusair KK, Kwun DJW. Information technology applications and competitive advantage in hotel companies [Internet]. Vol. 2, Journal of Hospitality and Tourism Technology. 2010 [cited 2018 Oct 18]. p. 139-53.

34. Ying Lu, Ramamurthy K (Ram). Understanding The Link Between Information Technology Capability and Organizational Agility: an Empirical Examination. MIS Q. 2011;35(4):931-54.

35. Sambamurthy V, Lee D, Wei K-K, Lim K. IT-Enabled Organizational Agility and Firms' Sustainable Competitive Advantage. In: International Conference on Information Systems [Internet]. 2007 [cited 2018 May 17].

36. Chen Y, Wang Y, Nevo S, Jin J, Wang L, Chow WS. IT capability and organizational performance: The roles of business process agility and environmental factors. Eur J Inf Syst [Internet]. 2014 May 26 [cited 2017 Sep 20];23(3):326-42.

https://doi.org/10.1057/ejis.2013.4

37. Bhatt GD, Grover V. Types of information technology capabilities and their role in competitive advantage: An empirical study. J Manag Inf Syst. 2005;22(2):253-77.

38. Degroote SE, Marx TG. The impact of IT on supply chain agility and firm performance: An empirical investigation. Int $\mathrm{J}$ Inf Manage [Internet]. 2013;33(6):909-16.

39. Mao H, Liu S, Zhang J, Deng Z. Information technology resource, knowledge management capability, and competitive advantage: The moderating role of resource commitment. Int $\mathrm{J}$ Inf Manage [Internet]. 2016;36(6):1062-74.

40. Svensson G. The theoretical foundation of supply chain management: A functionalist theory of marketing. Int $\mathbf{J}$ Phys Distrib Logist Manag. 2002;32(9):734-54.

41. Mentzer JT, DeWitt W, Keebler JS, Min S, Nix NW, Smith CD, et al. Defining Supply Chain Management. J Bus Logist [Internet]. 2001 Sep [cited 2018 Apr 26];22(2):1-25.

42. Li S, Nathan, Bhanu Ragu. Nathan RTS, Rao SS. The impact of supply chain management practices on competitive advantage and organizational performance. Int J Manag Sci. 2006;34(2):107-124.

43. Dove R. Response Ability: The Language, Structure, and Culture of the Agile Enterprise [Internet]. Vol. 1. 2001. $368 \mathrm{p}$.

44. Gligor DM, Esmark CL, Holcomb MC. Performance outcomes of supply chain agility: When should you be agile? J Oper Manag [Internet]. 2015 Jan [cited 2017 Sep 22];33-34:71-82.

45. Cao M, Zhang Q. Supply chain collaboration: Impact on collaborative advantage and firm performance. $\mathbf{J}$ Oper Manag [Internet]. 2011;29(3):163-80.

46. Gligor DM. The role of demand management in achieving supply chain agility. Supply Chain Manag. 2014;19(October 2013):577-91.

47. Swafford PM, Ghosh S, Murthy N. Achieving supply chain agility through IT integration and flexibility. Int J Prod Econ. 2008;116(2):288-97.

48. Swafford PM, Ghosh S, Murthy N. The antecedents of supply chain agility of a firm: Scale development and model testing [Internet]. Vol. 24, Journal of 
Operations Management. 2006 [cited 2017 Sep 24]. p. $170-88$.

49. Vickery SK, Jayaram J, Droge C, Calantone R. The effects of an integrative supply chain strategy on customer service and financial performance: An analysis of direct versus indirect relationships. J Oper Manag. 2003;21(5):523-39.

https://doi.org/10.1016/j.jom.2003.02.002

50. Tse YK, Zhang M, Akhtar P, MacBryde J. Embracing supply chain agility: an investigation in the electronics industry. Supply Chain Manag An Int J. 2016 Jan 11;21(1):140-56.

51. Gandhi AV, Shaikh A, Sheorey PA. Impact of supply chain management practices on firm performance: Empirical evidence from a developing country. Int $\mathbf{J}$ Retail Distrib Manag [Internet]. 2017 Apr 10 [cited 2019 Jan 15];45(4):366-84.

52. Gligor DM, Holcomb MC. Antecedents and consequences of supply chain agility: Establishing the link to firm performance. J Bus Logist. 2012;33(4):295-308.

53. Gligor DM, Holcomb MC, Stank TP. A multidisciplinary approach to supply chain agility: Conceptualization and scale development. J Bus Logist. 2013;34(2):94-108.

54. Hamister JW. Supply chain management practices in small retailers. Int $\mathrm{J}$ Retail Distrib Manag. 2012;40(6):427-50.

55. Oosterhout M Van, Waarts E, Axelsson R. Business Agility: Need, Readiness and Alignment with IT Strategies. In: Agile Information Systems: Conceptualization, Construction, and Management. 2007. p. 52-69.

56. Lee OK, Sambamurthy V, Lim KH, Wei KK. How does IT ambidexterity impact organizational agility? Inf Syst Res [Internet]. 2015 Jun [cited 2018 Mar 1];26(2):398-417.

57. Newbert SL. Value, rareness, competitive advantage, and performance: A conceptual-level empirical investigation of the resource-based view of the firm. Strateg Manag J [Internet]. 2008 Jul [cited 2018 May 17];29(7):745-68.

https://doi.org/10.1002/smj.686

58. Bartlett JE, Kotrlik JW, Higgins CC. Organizational Research: Determining Appropriate Sample Size in Survey Research Appropriate Sample Size in Survey Research [Internet]. Vol. 19, Information Technology, Learning, and Performance Journal. 2001 [cited 2019 Jul 15].

59. Israel GD. Determining Sample Size [Internet]. 2003 [cited 2019 Jul 18].

60. Cochran WG. Sampling Techniques. Vol. 3, Journal of economics and finance. 1977. 77-728 p.

61. Barney JB. Purchasing, Supply Chain Management and Sustained Competitive Advantage: The Relevance of Resource-based Theory. J Supply Chain Manag [Internet]. 2012 Apr [cited 2018 Oct
15];48(2):3-6.

62. Rinta-Kahila T, Penttinen E, Nevalainen A. Unfolding the types of organizational inertia in information systems adoption. Proc Annu Hawaii Int Conf Syst Sci. 2016;2016-March:3908-17. 